\title{
СКРИНИНГ КОЛЛЕКЦИОННЫХ ОБРАЗЦОВ СОИ ПО СКОРОСПЕЛОСТИ И ПРОДУКТИВНОСТИ В УСЛОВИЯХ РЯЗАНСКОЙ ОБЛАСТИ
}

\section{Е.В. Гуреева}

к.с.-Х.Н., ведущий научный сотрудник отдела селекции и семеноводства

Институт семеноводства и агротехнологий - филиал

ФГБНУ «Федеральный научный агроинженерный центр ВИМ», г. Рязань

Соя - стратегическая культура многоцелевого использования. Производство и потребление сои ежегодно возрастают. Использование культуры в продовольственных, кормовых, технических, фармацевтических и медицинских целях требует создания специализированных сортов с целевыми признаками, востребованными разной сферой применения [1].

Успех селекции зависит от правильного подбора исходного ма-

образцы, исходный материал, продуктивность, Рязанская область

Soybeans, collectable samples, parent material, productivity, Ryazan region териала. Не все образцы мировой коллекции пригодны для использования в селекции ввиду низкой продуктивности, экологической неприспособленности, биологической несовместимости и других отрицательных черт [2].

Целью наших исследований является изучение коллекционного материала сои в условиях Рязанской области и выявление в мировой коллекции скороспелых и высокопродуктивных образцов, адаптированных к условиям Центрального региона России.

\section{Условия и методы исследований}

Опыты проведены в Институте семеноводства и агротехнологий - филиале ФГБНУ ФНАЦ ВИМ, расположенном в лесостепной агроклиматической зоне, в Рязанской области. Почва опытного участка тёмно-серая лесная, тяжелосуглинистая. Реакция почвенного раство-

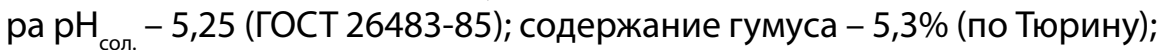
содержание подвижного фосфора - 34,0 мг/100 г почвы (по Кирсанову), обменного калия - 19,2 мг/100 г почвы (по Кирсанову), азота нитратного - 8,4 мг/кг (ГОСТ 26951-86), азота аммонийного - 1,57 мг/кг (ГОСТ 26489-85). Предшественник - озимая пшеница. Исследования проводили в 2015-2018 гг. За стандарт принят сорт Магева (Россия).

Агротехника общепринятая для возделывания сои в данном регионе [3]. В процессе исследований применяли методику государственного сортоиспытания [4] и «Международный классификатор сои СЭВ» [5]. Статистическая обработка данных согласно методике полевого опыта [7].

Метеорологические условия периода вегетации различались по температурному режиму и по количеству осадков. Наиболее благо- 
приятными для развития сои были 2015 и 2016 годы. 2017 год характеризовался пониженными температурами воздуха и недостаточным количеством влаги в мае, период созревания отличался повышенным количеством осадков: у сортов всех групп спелости удлинился период вегетации. На протяжении всего вегетационного периода 2018 года среднесуточная температура воздуха была выше среднемноголетних значений на $3-6^{\circ} \mathrm{C}$, в июне дефицит осадков составил $80 \%$.

Анализируя значения гидротермического коэффициента (ГТК), как интегрированного показателя атмосферных осадков и температуры воздуха, можно отметить, что наиболее продуктивным для формирования урожая сои был 2015 год, значение ГТК равно 1,02.

\section{Результаты исследований}

В коллекционном питомнике изучалось 224 образца сои из 30 стран, в т.ч. 52\% сортов отечественной селекции (рис. 1).

Вегетационный период изменялся в зависимости от погодных условий и составил от 79 до 123 суток. Ежегодно самыми скороспелыми сортами были сорта российской селекции - Эльдорадо, СибНИИК-315, Касатка, Светлая; сорта шведской селекции - Brawalla и 13-84 и сорт Прогресс (Польша). Эти сортообразцы представляют интерес для селекции по признаку скороспелости в условиях Рязанской области.

На основании средней продолжительности вегетационного периода изученные образцы отнесены к пяти группам спелости, у большинства образцов продолжительность периода от всходов до созревания составляет 91-110 дней.
Исследования выявили дифференциацию по продуктивности по сортам: масса семян с растения варьировала от 3,1 до 22,2 г. Максимальная продуктивность в годы исследований (22,5 г) отмечена у сорта Аметист (Украина) в 2016 году. По продуктивности семян между образцами различного эколого-географического происхождения достоверных различий не выявлено.

Как показал корреляционный анализ, продуктивность растений сои во все годы исследований зависела от количества семян на растении $(r=0,827)$ и количества продуктивных узлов на растении $(r=0,738)$.

Максимальное число продуктивных узлов на одном растении - 25,4 шт. (157\% к стандарту) сформировалось в 2016 году у Gaterslebener stamm 54/14 (Австралия). Минимальное (67\% к стандарту) - у сорта Припять (Беларусь) в 2017 году. Число продуктивных узлов у районированных по третьему региону сортов в среднем за годы исследований составило 9,3-15,4 шт.

Число бобов на растении варьировало от 20,0 до 67,3 шт. Наибольшее количество бобов отмечено у образцов F 50R/kw (Франция), Лира (Россия), Мерлин (Австрия), Daksoy (США), Лондон (Австрия). У сортов, районированных по третьему региону, число бобов на растении составляет от 22,9 до 38,2 шт.

Количество семян на растении изменялось от 35,5 у сорта Arotik (Польша) с периодом вегетации 110 дней до 128,9 шт. у сорта Мерлин (Австрия) с периодом вегетации 118 дней. Наибольшее значение данного показателя - у сортов: ОАС Erin (Канада), Лира (Россия), Semu 315 (Германия), Касатка (Россия). Эти образцы представляют ин-
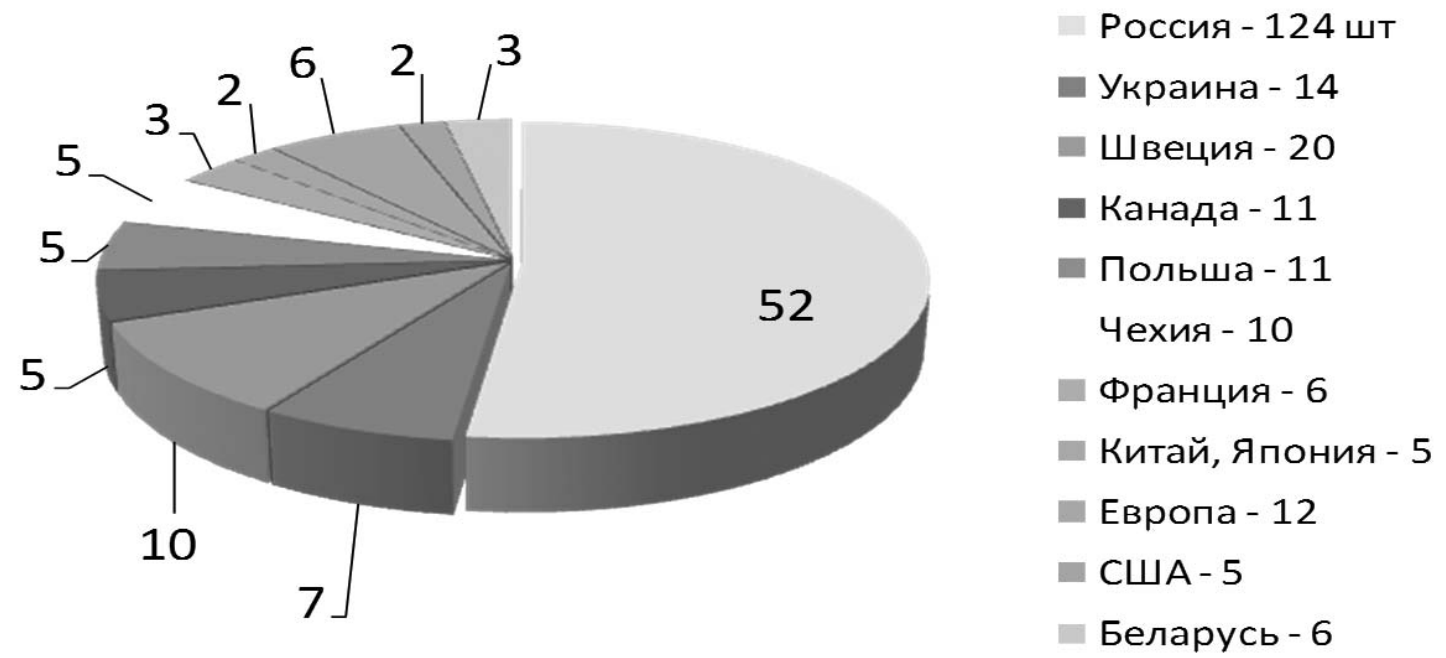

Рисунок 1 - Распределение образцов сои мировой коллекции по происхождению, \% 
терес для селекции по признаку продуктивности в условиях Рязанской области. У стандарта количество семян на растении - 63,7 штук, у сортов, районированных по третьему региону, от 54,0 до 95,1 шт.

В годы исследований число семян в бобе по группам спелости варьировало незначительно, большинство образцов имели 1,6-2,5 семени в бобе (малое число по классификатору). Максимальное количество семян в бобе (2,5 шт.) сформировалось у сорта Касатка (Рязанская обл.), минимальное (1,52 шт.) у сорта RHAR 78/B (Польша).

Масса 1000 семян варьировала от 110 до 247 г. Максимальную массу 1000 семян имел сорт 856-3-34 (Швеция) - 247 г; наименьшую - сорт LF19 (Польша).

Высота прикрепления нижнего боба в опытах варьировала от 9,1 см у сорта MON-04 (США) до
22,3 см у сорта Анастасія (Украина). Корреляционная зависимость между высотой прикрепления нижнего боба и высотой растения составляет $r=0,471$, между высотой прикрепления нижнего боба и продолжительностью вегетационного периода $r=0,416$.

При изменяющихся погодных условиях важным показателем сортов является их устойчивость к стрессу, уровень которого определяется по разности между минимальной и максимальной урожайностью (У2 - У1). Установлено, что самую высокую устойчивость к стрессу $(-3,7)$ имеют сорт Елена (Украина) и линия Н-17/09 (Россия). Самую низкую стрессоустойчивость имели сорта Мерлин $(-13,6)$ и MON-04 $(-13,5)$ (табл. 1).

Урожайность семян в 2015-2018 годах сильно зависела от погодных условий: наиболее уро-

Таблица 1 - Показатели продуктивности и стрессоустойчивости сортов сои (2015-2018 гг.)

\begin{tabular}{|c|c|c|c|c|c|}
\hline $\begin{array}{c}\text { № } \\
\Pi / \Pi\end{array}$ & Название сорта & Происхождение & У2 - У1 & $\frac{\mathrm{y} 1+\mathrm{y} 2}{2}$ & $\begin{array}{c}\text { Размах варьирования } \\
\text { продуктивности } \\
\text { (min - max), г/раст. }\end{array}$ \\
\hline 1 & Магева & Рязанская область & $-5,7$ & 7,35 & $5,1-10,8$ \\
\hline 2 & Касатка & Рязанская область & $-12,5$ & 9,95 & $3,7-16,2$ \\
\hline 3 & Чера 1 & Чувашия & $-5,1$ & 9,05 & $9,4-14,5$ \\
\hline 4 & Semu 315 & Германия & $-9,3$ & 9,25 & $4,6-13,9$ \\
\hline 5 & MON-04 & США & $-13,5$ & 8,95 & $3,1-16,6$ \\
\hline 6 & Gaillard & Канада & $-7,2$ & 13,1 & $9,6-16,8$ \\
\hline 7 & УСХИ-6 & Ульяновская область & $-7,2$ & 9,2 & $5,6-12,8$ \\
\hline 8 & Мерлин & Австрия & $-6,2$ & 14,5 & $9,2-19,8$ \\
\hline 9 & Гармония & Амурская область & $-10,3$ & 8,65 & $5,9-11,5$ \\
\hline 10 & Елена & Украина & $-3,7$ & 9,45 & $8,7-12,4$ \\
\hline 11 & Лира & Краснодарский край & $-11,1$ & 10,55 & $6,4-13,1$ \\
\hline 12 & Светлая & Рязанская область & $-8,3$ & 8,75 & $3,9-9,8$ \\
\hline 13 & Н-17/09 (Славянка) & Рязанская область & $-3,7$ & 7,65 & $5,8-9,6$ \\
\hline 14 & Георгия & Рязанская область & $-6,4$ & 10,4 & $7,2-13,6$ \\
\hline 15 & Окская & Рязанская область & $-7,8$ & 8,15 & $5,3-12,1$ \\
\hline
\end{tabular}

жайными были сорта Мерлин (Австрия) и Gaillard (Канада). Об этом свидетельствует такой показатель как $(\mathrm{У} 1+\mathrm{Y} 2 / 2)$. Данный показатель отражает среднюю урожайность сорта в контрастных (стрессовых и нестрессовых) условиях и характеризует генетическую гибкость сорта, его компенсаторную способность [6].

\section{Выводы}

В результате изучения сортов сои различного эколого-географического происхождения в условиях Рязанской области выделены сорта, сочетающие повышенную продуктивность с оптимальной продолжительностью вегетационного периода. Полученные новые знания будут 
использованы в практической селекции при создании новых сортов, адаптированных к условиям Центрального региона России. При селекции сои на продуктивность необходимо учитывать количество продуктивных узлов, бобов и семян на растении. Селекция на скороспелость осуществляется с учётом пригодности сортов к механизированной уборке.

\section{תumepamypa}

1. Вишнякова, М.А. Требования к исходному материалу для селекции сои в контексте современных биотехнологий (обзор) [Текст] / М.А. Вишнякова, И.В. Сеферова, М.Г. Самсонова // Сельскохозяйственная биология. - 2017. - Том 52. - № 5. - С. 905-916.

2. Неттевич, э.Д. Избранные труды. Селекция и семеноводство яровых зерновых культур [Текст] / Э.Д. Неттевич. - М.: Немчиновка, 2008. - С. 40-43, 163-169.

3. Гуреева, Е.В. Инновационная технология возделывания сои в хозяйствах Центрального района Нечерноземной зоны: библиотечка «в помощь консультанту» [Текст] / Е.В. Гуреева, М.П. Гуреева, Т.А. Фомина [и др.]. - М.: ФГУ «Российский центр сельскохозяйственного консультирования», 2008. - 34 с.

4. Методика государственного сортоиспытания сельскохозяйственных культур [Текст]. - М.: Колос, 1989. - 267 с.

5. Международный классификатор СЭВ [Текст]. - Ленинград: ВИР, 1990. - 39 с.

6. Гончаренко, А.А. Об адаптивности и экологической устойчивости сортов зерновых культур [Текст] / А.А. Гончаренко // Вестник Россельхозакадемии. - 2005. - № 6. - С. 49-53.

7. Доспехов, Б.А. Методика полевого опыта [Текст] / Б.А. Доспехов. - М.: Агропромиздат, 1985. - 351 с.

\section{References}

1. Vishnyakova, M.A. Trebovanija $\mathrm{k}$ ishodnomu materialu dlja selekcii soi $v$ kontekste sovremennyh biotehnologij (obzor) [Tekst] / M.A. Vishnyakova, I.V. Seferova, M.G. Samsonova // Sel'skohozjajstvennaja biologija. - 2017. - Tom 52. - № 5. - S. 905-916.

2. Nettevich, Eh.D. Izbrannye trudy. Selekcija i semenovodstvo jarovyh zernovyh kul'tur [Tekst] / Eh.D. Nettevich. - M.: Nemchinovka, 2008. - S. 40-43, 163-169.

3. Gureeva, E.V. Innovacionnaja tehnologija vozdelyvanija soi v hozjajstvah Central'nogo rajona Nechernozemnoj zony: bibliotechka «v pomoshh' konsul'tantu» [Tekst] / E.V. Gureeva, M.P. Gureeva, T.A. Fomina [i dr.]. - M.: FGU «Rossijskij centr sel'skohozjajstvennogo konsul'tirovanija», 2008. - $34 \mathrm{~s}$. $267 \mathrm{~s}$.

4. Metodika gosudarstvennogo sortoispytanija sel'skohozjajstvennyh kul'tur [Tekst]. - M.: Kolos, 1989. -

5. Mezhdunarodnyj klassifikator SJeV [Tekst]. - Leningrad: VIR, 1990. - 39 s.

6. Goncharenko, A.A. Ob adaptivnosti i jekologicheskoj ustojchivosti sortov zernovyh kul'tur [Tekst] / A.A. Goncharenko // Vestnik Rossel'hozakademii. - 2005. - № 6. - S. 49-53.

7. Dospekhov, B.A. Metodika polevogo opyta [Tekst] / B.A. Dospekhov. - M.: Agropromizdat, 1985. - 351 s. 